\title{
RISK MODELING FOR WETLAND RESTORATION INVESTMENTS
}

\author{
Evgeny Davydov ${ }^{1}$, Inna Davydova ${ }^{2}$, Yury Mazhayskiy ${ }^{3}$ \\ ${ }^{1}$ Dubna State University, Russia; ${ }^{2}$ Ryazan State University named after S.A. Yesenin, Russia; \\ ${ }^{3}$ All-Russian Research Institute of Hydrotechnics and Melioration \\ named after A.N. Kostyakova, Russia \\ eugene00@mail.ru,diu2004@mail.ru,director@mntc.pro
}

\begin{abstract}
Sustainable development of rural areas with wetlands was a priority goal of the study. Natural fires are the main cause of destruction of peat bog soils. As a rule, drained peatlands suffer from fires to the greatest extent. Therefore, there are investment risks that limit the sustainable development of rural areas. To reduce the risks, a program of flooding of peatlands is being implemented. Previously, it was found that this technological process leads to a drop in the value of land plots. The aim of the study is to model the risks associated with wetland restoration and to optimize the social and economic consequences of this technological process. The object of the study is a complex of natural and social conditions in the rural territory of the Ryazan Meshchera. The subject of the study is optimization of the selection of rural areas in the Ryazan Meshchera for the flooding of peatlands. The study is based on analytical modeling of the search for sites with the lowest investment risks. The results of the study are presented in the form of maps. These maps allow to diagnose places with the lowest investment risk due to the high efficiency of peat bogging projects and the favorable attitude of the local population. There were also developed proposals related to improving the comfort of life of the rural population in areas with restored wetlands. Reclamation measures were recommended to protect peat soils from fires and to restore specialized agriculture on drained peatlands.
\end{abstract}

Keywords: risk modeling, peatlands, wetlands restoration.

\section{Introduction}

Wetland restoration is essential for areas with drained peatlands. First, it is necessary to protect the local population from forest fires. Secondly, the flooding of peatlands can reduce the emission of carbon dioxide into the atmosphere and slow down global warming.

According to Parish F. and others, the protection and restoration of peatlands is the most cost effective measure to mitigate global climate change [1].

However, the question of the economic feasibility of restoring peatlands remains debatable among land managers, researchers and practitioners [2].

In Russia, the peat bog restoration project is being implemented with the support of the state, the International Climate Initiative and the International Organization for Wetland Restoration [3].

Abramchuk M. and others emphasize the relevance of accounting and in-depth analysis of certain costs and benefits of secondary flooding of swamps in European Russia [4].

We believe that the problem is related to environmental and social risks, which are currently poorly understood for peat bog restoration projects in European Russia, including the Ryazan Meshchera. The main reason for these risks is the location of forest and agricultural land, as well as settlements, on previously drained peatlands.

The purpose of our research is to create an analytical model for assessing investment risks environmental and social-when changing the reclamation status of land with fire-hazardous peatlands. Such an analytical model is necessary to select the territory with the highest efficiency of investment projects for waterlogging peatlands. This model is also intended for social advertising of restoration of wetlands to ensure fire safety in the Ryazan Meshchera.

\section{Materials and methods}

The object of the study is the territory of the Ryazan Meshchera, where the most fire-hazardous landscapes are located. Coniferous-deciduous forests and peat bogs predominate here. Many swamps were drained.

First, we developed principles of an analytical model for assessing environmental risk in wetland restoration and after that we had two constructed maps: 1- modeled reduction of fire risks associated with changes in soil as a result of wetland restoration; 2 - modeled levels of land fire risks for localities [5]. 
Then we took into account the social risks.

We had the results of opinion polls published earlier [6]. A total of 533 people were interviewed in 11 localities. We took into account the opinion of the local population about the desire to leave because of the threat of fires. We also found out the economic expectations of people in connection with the flooding of peatlands. Social surveys were conducted in rural areas, which are located among forests and peatlands. There are no large settlements. The surveys involved the local population of Ryazan and Moscow regions, as well as those who have cottages and land plots for recreation. The respondents included all gender and age groups. In each of the considered localities, we determined the percentage of respondents from the total number of respondents who answered the questions in Table 1.

Social survey sites have now been digitized. The amount of work is 55 points.

Equally important is the consideration of the social risks associated with the restoration of wetlands. To assess the attitude of the local population to such projects, we used the data of the conducted sociological surveys. Namely, for each $i$-th locality, we compiled Table 1 of coefficients $K_{n, i}$.

Setting table of social risk factors for wetland restoration

Table 1

\begin{tabular}{|l|c|}
\hline \multicolumn{1}{|c|}{ Question } & $\begin{array}{c}\text { \% of those who } \\
\text { answered in affirmative }\end{array}$ \\
\hline $\begin{array}{l}\text { In case of purposeful flooding of the peat bog nearby to } \\
\text { your settlement, do you expect improvement of your } \\
\text { living conditions? }\end{array}$ & $K_{1, i}$ \\
\hline $\begin{array}{l}\text { In case of purposeful flooding of the peat bog nearby to } \\
\text { your settlement, do you expect deterioration of your } \\
\text { living conditions? }\end{array}$ & $K_{2, i}$ \\
\hline $\begin{array}{l}\text { Do you expect an increase in the market value of your } \\
\text { property when the peat bog nearby to your locality is } \\
\text { flooded and the land is likely to become waterlogged? }\end{array}$ & $K_{3, i}$ \\
\hline $\begin{array}{l}\text { Do you expect a decrease in the market value of your } \\
\text { property when the peat bog nearby to your locality is } \\
\text { flooded and the land is likely to become waterlogged? }\end{array}$ & $K_{4, i}$ \\
\hline
\end{tabular}

Using these data, we built a model of the attitude of the local population to wetland restoration projects. Assuming a normal (Gaussian) distribution, we extrapolated the data to the surrounding land plots using the formula (1):

$$
E(x, y)=\frac{1}{2} \sum_{i=1}^{N_{E}}\left(K_{1, i}-K_{2, i}+K_{3, i}-K_{4, i}\right) e^{-\frac{\left(x-x_{i}\right)^{2}+\left(y-y_{i}\right)^{2}}{2 d_{E}}},
$$

where $E(x, y)$-indicator of the ratio at a point with coordinates $(x, y)$, varying in the range from -100 to +100

$\left(x_{i}, y_{i}\right)$ - coordinates of the $i$-th locality from the data of sociological surveys;

$N_{E}$ - total number of such localities;

$d_{E}$ - average distance between these localities, calculated using a formula similar to the one above for $d_{R}$.

Then we built a map of the population ratio levels (negative, rather negative, neutral, rather positive, positive), see Fig. 1. These levels correspond to an increase in the value of $E(x, y)$ from -100 to 100 .

Despite the fact that the list of localities in which sociological surveys were conducted only slightly overlaps with the list of localities with a high fire risk, the constructed maps (1 and 2) are in good correlation with each other. In those areas of the Ryazan region where the risk of fires is high, the population has a positive attitude to waterlogging projects, and on land with a low level of fire hazard, waterlogging projects may be exposed to social risks due to the negative attitude of local residents to waterlogging the territory. 


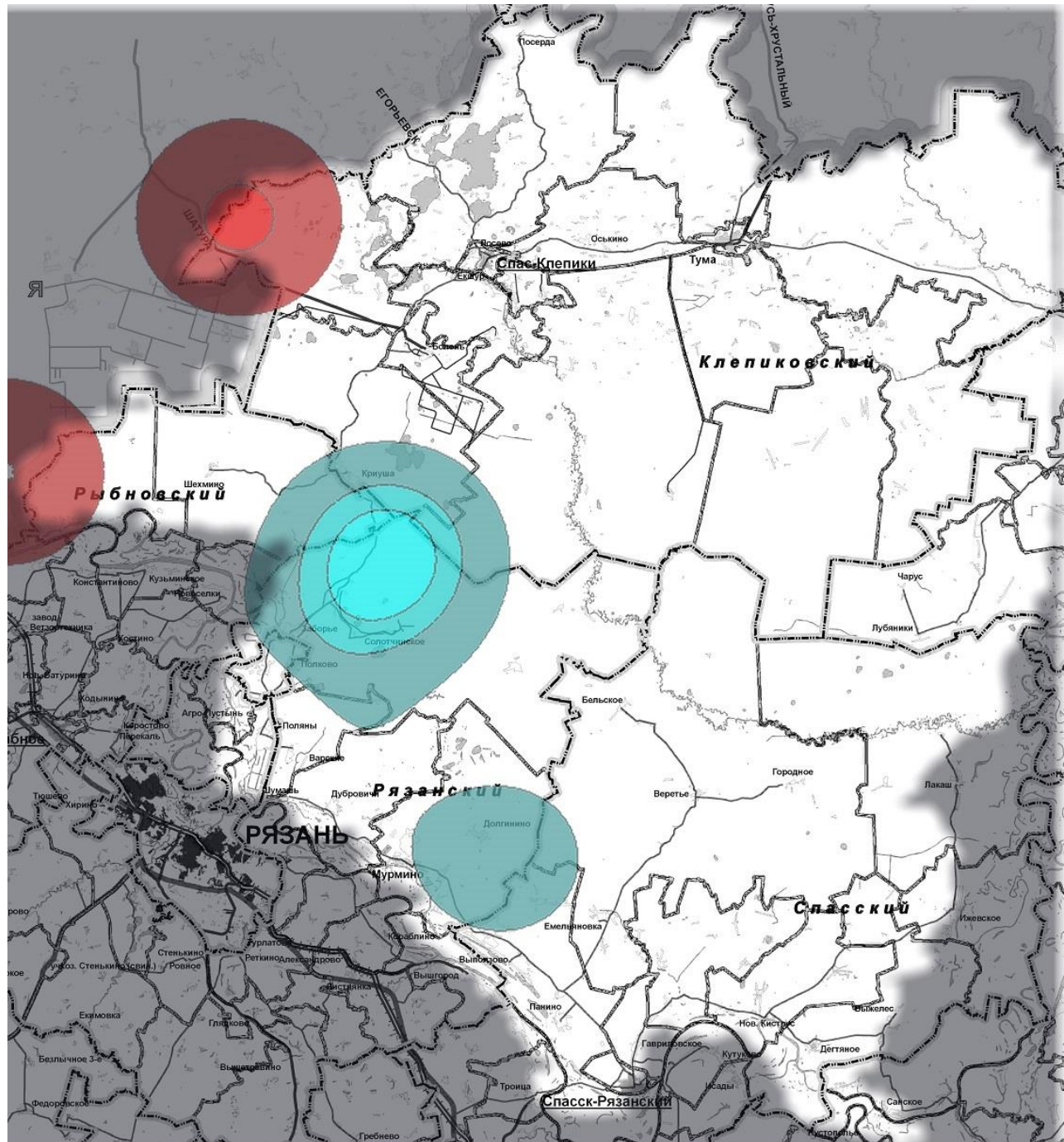

Local community attitudes towards wetland restoration

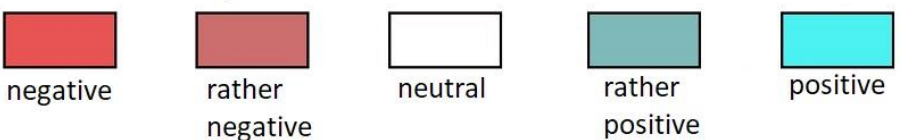

Fig. 1. Simulated map of social risks of wetland restoration projects

\section{Results and discussion}

Using all available data, we can build an analytical model that allows us to assess investment risks (environmental and social), when changing the reclamation status of land with fire-hazardous peatlands. Social risks are set by the value $E$ (the higher its value, the lower the risks). And to assess environmental risks, it is necessary to bring together data on the reduction of soil fire hazard when the land reclamation status changes (map 1) and data on the actual fire hazard risks (map 2). The relevance of this combination of data is quite obvious: reducing the risks of fire hazard of soils is in demand only where the risk of fires is high. If in some area the forest fire threats are insignificant, then additional risk reduction does not have much effect. On the contrary, in areas that regularly suffer from forest fires, even a moderate reduction in the fire hazard of the soil will be of great benefit. The combined data are shown in Fig. 2 .

To demonstrate the application of the analytical model, we divided the map 1 into 16 regions (approximately $25 \times 25 \mathrm{~km}$ in size): first, the Meshchera map was divided into 4 quadrants (northwest, northeast, southwest, southeast), and then each of the quadrants was also divided into 4 subdomains. Of these 16 regions, we have left for consideration only those 12 , for which most of the land really belongs geographically to the lands of the Ryazan Meshchera. 


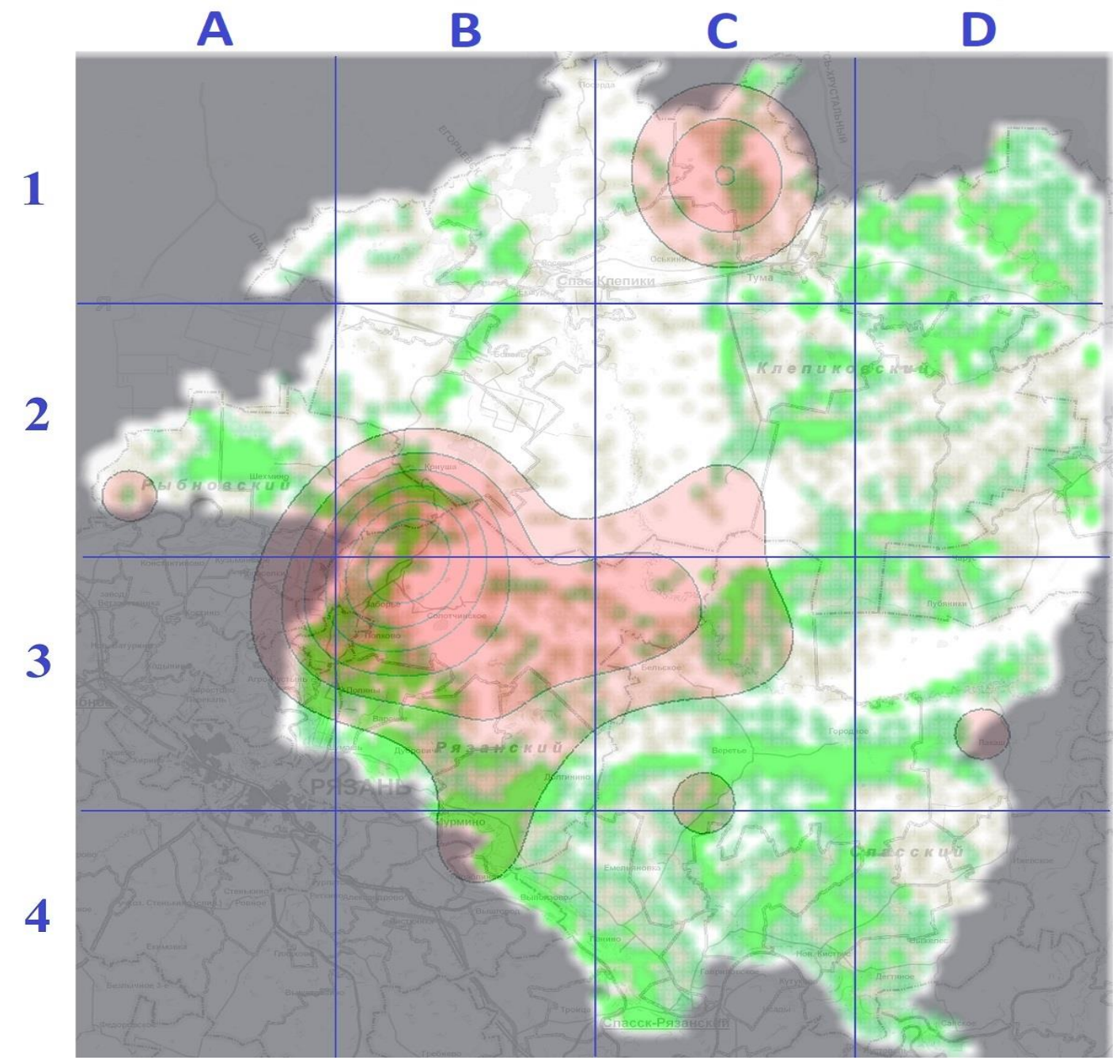

Fig. 2. Combined environmental risk map: current forest fire risk and expected risk reduction after changes in the land reclamation status of fire-prone peatlands

You can see that within each of the 12 areas, the distribution of map elements is fairly uniform, which allows us to build integral characteristics for each of the 16 areas and evaluate them with points according to Table 2 .

Table 2

Setting table of environmental and social risk scores for wetland restoration

\begin{tabular}{|c|c|c|c|c|c|}
\hline $\begin{array}{c}\text { Current fire hazard } \\
\text { level, R (from the } \\
\text { map 2) }\end{array}$ & Points & $\begin{array}{c}\text { Potential reduction of } \\
\text { fire hazard, D (from } \\
\text { the map 1) }\end{array}$ & Points & $\begin{array}{c}\text { Population } \\
\text { ratio, E (from } \\
\text { Fig. 1) }\end{array}$ & Points \\
\hline insignificant & 0 & absent & 0 & negative & 0 \\
\hline low & 1 & low & 1 & rather negative & 1 \\
\hline average & 2 & average & 2 & neutral & 2 \\
\hline high & 3 & high & 3 & rather positive & 3 \\
\hline very high & 4 & - & - & positive & 4 \\
\hline
\end{tabular}

It is also convenient to present the results of the assessment in the form of Table 3. Note that in the eastern part of Meshchera, no opinion polls were conducted, so the data may not be completely relevant. Therefore, it is appropriate to analyze the results for the western part (areas A2-A3, B1-B3). According to the proposed model, the most effective and appropriate projects should be wetland restoration projects 
in areas that have scored more than half of the maximum possible number of points (11), i. e. 6 or more. These include areas B2 and B3.

\section{Investment risks for Meshchera lands during wetland restoration, expressed as integral points (more points - less risks)}

Table 3

\begin{tabular}{|c|c|c|c|c|}
\hline Area & $\boldsymbol{R}$ & $\boldsymbol{D}$ & $\boldsymbol{E}$ & Total, $\boldsymbol{I}$ \\
\hline A2 & 1 & 2 & 1 & 4 \\
\hline B1 & 0 & 1 & 1 & 2 \\
\hline B2 & 2 & 1 & 3 & 6 \\
\hline B3 & 4 & 2 & 4 & 10 \\
\hline C1 & 3 & 1 & 2 & 6 \\
\hline C2 & 1 & 1 & 2 & 4 \\
\hline C3 & 2 & 2 & 3 & 7 \\
\hline C4 & 0 & 3 & 3 & 6 \\
\hline D1 & 0 & 3 & 2 & 5 \\
\hline D2 & 0 & 3 & 2 & 5 \\
\hline D3 & 1 & 2 & 2 & 5 \\
\hline D4 & 0 & 2 & 2 & 4 \\
\hline
\end{tabular}

It can be summarized that the "leader" was the B3 region, for which waterlogging projects will show high efficiency and favourable attitude of the local population. However, the B2 area, although it showed a sufficient score, is on the verge of efficiency. The types of soils present there will not have much effect in reducing the fire hazard after waterlogging. And the inevitable change in the nature of land use (reduction in the efficiency of agriculture and/or forestry and deterioration of conditions for peat mining) will give a noticeable negative economic effect. Therefore, a good candidate for waterlogging is the $\mathrm{C} 3$ area. It is highly unlikely that the high score scored by the $\mathrm{C} 3$ region will fall below 6 in the case of refined opinion polls. The final investment risks for the projects implemented on the B3 and C3 lands are the lowest among all the lands in the Ryazan Meshchera. The projects implemented on the $\mathrm{B} 1$ lands are in the greatest risk zone.

Note that large enough land plots are still characterized by large-scale heterogeneities, which makes such an integral point approach not quite accurate. In this case, the result can be improved by using a differentiated approach: a large land plot must be divided into smaller homogeneous blocks, calculate the points separately for the blocks using the formula $I=R+D+E$, and calculate the average value of $I$.

Should wetlands be restored or not in areas with even the lowest environmental and social risks? We believe that secondary flooding of peatlands is an extreme measure, as it significantly violates the living conditions of the rural population. It is preferable, in our opinion, to rationally use drained peatlands in agriculture and forestry. For example, you can make a two-way regulation of the water regime of peatlands and grow perennial grasses for animal husbandry.

We believe that there are two main approaches to solving the problem of restoring degraded peatlands in the world. In the first case, it is proposed to flood the peatlands to preserve not only the landscape, but also the economic way of life of the local population. For example, this approach exists in the regions of South-East Asia.

For example, a study of the degradation of peatlands in Kalimantan, Indonesia due to deforestation, drainage and fires has also shown the need for large-scale measures to restore the landscape. For the successful restoration of degraded peatlands, it was recommended to take into account scientific knowledge about both the soil cover, vegetation, water, and socio-economic circumstances, including the consent of the local population [7]. Other researchers also suggest wet farming and forestry on peatlands, or paludiculture, in order to provide the population around the peatlands with a livelihood in Indonesia [8]. However, both authors do not have an analytical model for assessing environmental and social risks, which allows you to choose the most preferred land for investment in large-scale restoration of degraded peatlands. 
In the second case, flooding of degraded peatlands is mainly associated with the restoration of peat extraction in Ireland [9]. Obviously, the priority of this economic goal suppresses the need to take into account environmental and social risks.

Nevertheless, we believe that an ecological and social approach to solving the problem of flooding of degraded peatlands is more preferable. This allows to reduce investment risks. It is important to take into account the experience of those regions, where the restoration of peatlands has been taking place for many years. For example, in North America, the restoration of peatlands over 25 years has shown the need for more extensive justification, including consideration of both natural factors and environmental impacts, as well as the interests of government agencies at various levels, legal requirements, and banking [10]. The analytical model developed by us allows to close some of the gaps in these studies in order to successfully restore peatlands in the interests of industry, agriculture and society.

\section{Conclusions}

1. Modelling the investment risk associated with wetland restoration should take into account environmental, economic and social factors.

2. The analytical model is based on digitized information about the fire hazard classes of soils, economic use of land, location of settlements most susceptible to natural fires, and the results of sociological surveys of the local population. In addition to the mathematical description, it includes cartographic models that assess the reduction of various risks. This is a map of fire risk reduction associated with soil changes due to waterlogging; a map of forest fire risks; and a map of the social risks of wetland restoration projects.

3. As a result, a combined environmental risk map was created, which predicts the current risk of forest fires and the expected risk reduction after the change in the reclamation status of land with fire-hazardous peatlands. Using this cartographic analytical model, the territory of the Ryazan Meschera was ranked according to the degree of investment risk in the restoration of wetlands. Areas with different efficiency of peatland waterlogging projects were identified. For example, in the south-western part of the Ryazan Meshchera, these projects will have the greatest efficiency and favorable attitude of the local population.

\section{Acknowledgements}

The reported study was funded by RFBR according to the research project No. 17-12-62002.

\section{References}

[1] Parish F., Sirin A.A., Charman D. etc. Assessment on peatlands, biodiversity and climate change. Kuala Lumpur, Wageningen: Wetlands International, 2008. 179 p.

[2] Moxey A., Moran D. UK peatland restoration: some economic arithmetic. The Science of the Total Environment, vol. 484, no. 1, 2014, pp. 114-120.

[3] Каменнова И.Е., Минаева Т.Ю. Проект «Восстановление торфяных болот в России в целях предотвращения пожаров и смягчения изменений климата»: опыт реализации и перспективы (Project "Restoration of peat Bogs in Russia to prevent fires and mitigate climate change": implementation experience and prospects). Proceedings of the International scientific and practical conference "Problems and Prospects of sustainable development of peat production in Russia", September 17-19, 2018, Tver, Russia, pp. 59-64. (In Russian).

[4] Abramchuk M., Gväbener U., Wichtmann W. etc. Arguments, costs and benefits for peatland restoration in European Russia. Proceedings of the International scientific and practical conference "Problems and Prospects of sustainable development of peat production in Russia", September 1719, 2018, Tver, Russia, pp. 6-11.

[5] Mazhayskiy Y., Davydov E., Davydova I. Principles of an analytical model for assessing environmental risk in wetland restoration. Proceedings of the $20^{\text {st }}$ SGEM International Multidisciplinary Scientific Geo-Conference SGEM 2020, August 18-24, 2020, Albena, Bulgaria, vol. 20, pp. 519-524.

[6] Давыдова И.Ю., Бирюкова Е.В., Горнов В.А. Социальные риски инвестиционных проектов по обводнению пожароопасных торфяников Рязанской Мещеры (Social risks of investment 
projects on flooding of fire-hazardous peatlands of the Ryazan Meshchera). Economics and Entrepreneurship magazine, vol. 11 (100), 2018, pp. 394-397. (In Russian).

[7] Page S., Hoscito A., Wősten H. etc. Restoration Ecology of Lowland Tropical Peatlands in Southeast Asia: Current Knowledge and Future Research Directions. Ecosystems, vol. 12, 2009, pp. 888-905.

[8] Budiman I., Sari E.N., Januar R. etc. Progress of paludiculture projects in supporting peatland ecosystem restoration in Indonesia. Global Ecology and Conservation, vol. 23, 2020, pp. e01084.

[9] Farrell C.A., Doyle G.J. Rehabilitation of industrial cutaway Atlantic blanket bog in county Mayo, North-West Ireland. Wetlands Ecology and Management, vol. 11, no. 1-2, 2003, pp. 21-35.

[10] Chimner R.A., Cooper D.J., Wurster R.C. etc. An overview of peatland restoration in North America: where are we after 25 years? Restoration Ecology, vol. 25, issue 2, March 2017, pp. 283292. 